\title{
Expression of the human androgen receptor in eukaryotic cells using a recombinant adenovirus vector yields high levels of the soluble, functional receptor protein
}

\section{S Zoppi, D R Allman, R D Gerard and M J McPhaul}

Department of Internal Medicine, Division of Endocrinology and Metabolism, University of Texas Southwestern Medical Center, Dallas, Texas 75235-8857, USA

(Requests for offprints should be addressed to M J McPhaul, Department of Internal Medicine, UT Southwestern Medical Center, 5323 Harry Hines Boulevard, Dallas, Texas 75390-8857, USA;

Email: michael.mcphaul@utsouthwestern.edu)

\begin{abstract}
The androgen receptor (AR) and closely related members of the steroid receptor family have proven difficult to obtain in native form in large quantities. In the case of the human AR (hAR), high-level expression in prokaryotic or non-mammalian cells leads to the synthesis of a high proportion of non-binding, insoluble, or degraded forms of the receptor protein.

To circumvent these difficulties, we have constructed a recombinant adenovirus that directs the expression of hAR under the control of a potent, constitutive promoter. Infection of eukaryotic cells
\end{abstract}

with this recombinant virus leads to the synthesis of large quantities of the intact AR. In contrast to expression methods designed to direct the fulllength AR in bacteria, yeast, and insect cells, AR expressed in mammalian cells using this adenoviral vector accumulates at high levels, retains many properties of the native AR, and is not rapidly proteolyzed. This method will prove useful for large-scale preparations of hAR for use in functional and structural studies.

Fournal of Molecular Endocrinology (2001) 27, 321-328

\section{INTRODUCTION}

The androgen receptor (AR) is a member of the nuclear receptor family and is most closely related to the mineralocorticoid, glucocorticoid and progesterone receptors (Mangelsdorf et al. 1995). These proteins have been shown to associate with macromolecular complexes that include heat shock proteins Hsp90 and 70, as well as p50 and FK506 binding proteins (Pratt \& Toft 1997, Smith et al. 1998, Liu \& DeFranco 1999, Freeman et al. 2000). It has been proposed that components of this complex are involved in folding the protein to its native, ligand-binding conformation and in masking its DNA-binding and transcription regulatory properties in the unliganded state.

A number of laboratories have employed a variety of expression techniques in eukaryotes and prokaryotes to prepare steroid receptors, including AR. Efforts to express AR in E. coli (Chang et al. 1989, Young et al. 1990, Nemoto et al. 1992, Roehrborn et al. 1992, Cooper et al. 1996, Snoek et al. 1996), yeast (Purvis et al. 1991, Mak et al. 1994, Caplan et al. 1995, Rana et al. 1998), and insect cells (Beitel et al. 1985, Chang et al. 1992, Kallio et al. 1993, Wong et al. 1993) have employed methods to express these proteins either in the unaltered state or as fusion proteins. Although these studies have uniformly accomplished the expression of the desired protein product, when the expressed receptor is examined carefully, it is clear that a significant proportion accumulates in an insoluble state, is unable to bind ligand, or is degraded due to proteolysis.

In this report, we detail the construction and use of a recombinant adenovirus that directs the expression of the human AR (hAR) in eukaryotic cells. This virus permits the preparation of large quantities of $\mathrm{AR}$ that retains physical and functional properties similar to the native receptor. This reagent will permit studies of the receptor and associated proteins, as well as experiments focused on the study of AR modification and turnover. 


\section{MATERIALS AND METHODS}

\section{Strain propagation and cell culture}

CV1 and 293 cells were obtained from the American Type Culture Collection (Manassas, VA, USA) and maintained as subconfluent stocks in Dulbecco's Modified Essential Medium containing 10\% fetal bovine serum. Adenovirus stocks were propagated by infection of 293 cells. Adenoviral DNA was prepared from the lysed cultures using standard techniques (Becker et al. 1994).

\section{Preparation of the recombinant expressing the His-tailed hAR}

Synthetic oligonucleotides were used to amplify the amino terminus of the hAR, inserting a synthetic NdeI restriction endonuclease cleavage site at the amino terminus. The AR open reading frame was excised as an NdeI-BamHI restriction endonuclease fragment, ligated into the bacterial expression vector pET 16-b (digested with NdeI and BamHI), and transformed into bacteria (plasmid C344). The entire open reading frame (including histidine tails) was removed from the $\mathrm{C} 344$ plasmid as a BglIIBamHI restriction endonuclease fragment and cloned into the pAC CMVpLpA shuttle vector at its unique BamHI restriction endonuclease cleavage site (Becker et al. 1994). Restriction endonuclease mapping and DNA sequence analysis confirmed orientation of the $\mathrm{AR}$ open reading frame. The resulting plasmid was designated $\mathrm{pAC}-\mathrm{His} \mathrm{AR}$.

A recombinant adenovirus encoding the Histailed AR was prepared by recombination in transfected 293 cells. The 293 cells were transfected with a mixture of the pAC-His AR plasmid $(10 \mu \mathrm{g})$ and $0 \cdot 1 \mu \mathrm{g}$ DNA derived from the right arm of adenovirus genomic DNA prepared from Ad5 d1327 by digestion with the restriction endonuclease ClaI. Twelve recombinant plaques were identified and expanded separately. A single clone (clone 6) was shown to direct the expression of high levels of immunoreactive AR (IRAR) when used to infect CV1 cells. After expansion and plaque purification, this virus was designated Ad His hAR and was used in subsequent experiments. (The number of amino acid residues differs for each of hAR cDNAs isolated, owing to variations in the lengths of the polymorphic glutamine repeat. The cDNA used in these studies is 917 amino acids long (Tilley et al. 1989).)

\section{Cellular fractionation}

At $48 \mathrm{~h}$ following infection with Ad His hAR, the CV1 cells were harvested, washed in PBS, and resuspended in TG high-salt buffer $(0.5 \mathrm{M} \mathrm{KCl}$, $10 \mathrm{mM}$ Tris, pH $7 \cdot 4,10 \%$ glycerol) containing proteinase inhibitors $(1 \cdot 0 \mu \mathrm{M}$ phenylmethylsulfonyl fluoride, $20 \mu \mathrm{g} / \mathrm{ml}$ pepstatin, $20 \mu \mathrm{g} / \mathrm{ml}$ leupeptin and $1 \%$ aprotinin $(\mathrm{v} / \mathrm{v}))$. After vortexing and sonicating, $100 \mu \mathrm{l}$ cell lysate were centrifuged at $14000 \mathrm{~g}$ for $20 \mathrm{~min}$. The pellet was resuspended in $100 \mu \mathrm{l}$ $2 \times$ loading buffer while $50 \mu \mathrm{l}$ supernatant were diluted with $50 \mu \mathrm{l} 2 \times$ loading buffer $(100 \mathrm{mM}$ Tris $\mathrm{pH}$ 6.9, $200 \mathrm{mM}$ dithiothreitol, 4\% sodium lauryl sulfate, $0.05 \%$ bromophenol blue, $20 \%$ glycerol). The supernatant (cytosol containing 'soluble' AR) and pellet ('insoluble' AR) fractions were stored at $-80^{\circ} \mathrm{C}$ until analyzed. Aliquots of $50 \mu \mathrm{l}$ cytosol and $25 \mu \mathrm{l}$ pellet fractions were loaded on the electrophoresis gel. In this way, equivalent portions of cytosol and pellet were analyzed.

\section{Immunoblot analyses}

Aliquots of cytosol and pellet fractions were diluted with $2 \times$ loading buffer, boiled for $5 \mathrm{~min}$, and electrophoresed on a $7 \cdot 5 \%$ polyacrylamide gel. Following electrophoresis, the samples were transferred to nitrocellulose filters, and incubated sequentially with polyclonal anti-peptide antibodies that recognize the amino-terminal 21 amino acids of AR (U402) (Husmann et al. 1990) and ${ }^{125}$ I-labeled anti-rabbit IgG (NEN Life Sciences, Boston, MA, USA). IRAR bands were visualized by autoradiography.

\section{Ligand-binding assays}

CV1 cells were plated in four-well plates at a density of $4 \times 10^{5}$ cells per well. Sixteen hours later, cells were infected with Ad His hAR at a multiplicity of infection (MOI) of 800 . At 24, 48, and $72 \mathrm{~h}$ after infection, the specific androgen-binding capacity was determined by adding medium containing $2 \mathrm{nM} \quad\left[1,2,4,5,6,7-{ }^{3} \mathrm{H}\right]-5 \alpha$-dihydrotestosterone (DHT) (specific activity $110 \mathrm{Ci} / \mathrm{mmol}$; NEN Life Sciences), in the presence or absence of a 200 -fold excess of unlabeled DHT. In saturation studies, the concentration of $\left[{ }^{3} \mathrm{H}\right] \mathrm{DHT}$ or $\left[{ }^{3} \mathrm{H}\right] \mathrm{mib}-$ olerone $(\mathrm{Mb})$ (specific activity $83.50 \mathrm{Ci} / \mathrm{mmol}$; NEN Life Sciences) varied from $0 \cdot 1 \mathrm{nM}$ to $3 \mathrm{nM}$. In competition studies, the specific binding was measured in the presence of different steroids (DHT, cortisol, progesterone and $17 \beta$-estradiol) at $1-, \quad 10$ - and 100 -fold excesses relative to the concentration of $\left[{ }^{3} \mathrm{H}\right] \mathrm{DHT}$. After incubation of the monolayers with the hormones for $1 \mathrm{~h}$ at $37^{\circ} \mathrm{C}$, the medium was removed. The cells were washed, trypsinized, washed and disrupted by sonication. Aliquots were assayed for radioactivity and protein 
content. The protein levels were determined by the Lowry assay. The results of specific binding assays were normalized to the cellular protein content and were expressed as $\mathrm{fmol} / \mathrm{mg}$ protein.

\section{Luciferase measurement}

CV1 cells were co-infected with the Ad His hAR and MMTV luciferase (Shih et al. 1991) adenoviruses in various proportions. Twenty-four hours following infection, the medium was removed and replaced with fresh medium containing 5\% charcoal-stripped serum containing either no hormone or $2 \mathrm{nM} \mathrm{Mb}$. Forty-eight hours later, the cells were harvested and luciferase activity was measured (Promega Corporation, Madison, WI, USA). Triplicate measurements were made for each condition tested.

\section{RESULTS}

\section{Properties of hAR expressed following infection with the recombinant adenovirus}

In initial experiments, we examined the level of expression of IRAR in cells following infection with the Ad His hAR (1-917) and determined that expression of IRAR was detectable in infected CV1 cells as soon as $6 \mathrm{~h}$ following infection. In these experiments, the levels of AR expression continued to increase for at least $72 \mathrm{~h}$ following infection (data not shown).

A major problem encountered in expressing AR at high levels in bacteria and in eukaryotic cells is the tendency of AR to precipitate and form insoluble aggregates. In addition to the increase in the insoluble AR that accumulates as the level of $\mathrm{AR}$ expression is increased, experiments in bacteria (Cooper et al. 1996) and mammalian cells (Roehrborn et al. 1992, M J McPhaul, unpublished observations) have demonstrated that increasing proportions of the soluble AR that accumulates are unable to bind hormone.

To characterize the nature of the AR expressed in the cells infected with the AR-expressing adenovirus, we performed experiments designed to examine the level and subcellular location of the IRAR that accumulates as a function of time. In Fig. 1, the level of adenovirus employed was fixed at an MOI of 800 and the level and nature of receptor expressed was examined by cell fractionation and immunoblotting. Although a large proportion of the IRAR was detected in the soluble fraction at each time point examined, the proportion and level of soluble receptor protein that accumulated

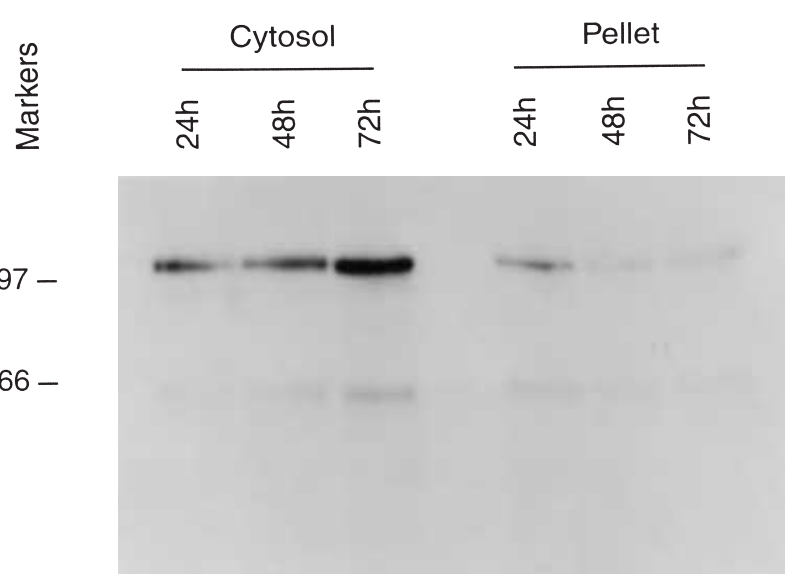

FIGURE 1. Time course of AR expression following infection with the Ad hAR (His 1-917) adenovirus. At $80 \%$ confluence, $10 \mathrm{~cm}$ plates of CV1 cells were infected with the Ad His hAR at a single MOI (800). Twentyfour, 48 and $72 \mathrm{~h}$ following infection, the cells were harvested and separated into cytosol and pellet fractions. The individual fractions were analyzed on a $7 \cdot 5 \%$ SDS polyacrylamide gel and transferred to nitrocellulose. IRAR was detected using an antibody directed at the amino terminus of hAR (U402). The sample quantities were adjusted such that equivalent portions of cytosol and pellet are represented in the immunoblot shown. The positions of molecular mass markers are indicated.

increased throughout this period and was maximal at $72 \mathrm{~h}$.

The effect of changes in the level of expression on the nature of the expressed AR was examined by the experiment depicted in Fig. 2. In this experiment, monolayers of CV1 cells were infected with the Ad His hAR using varying MOIs. Forty-eight hours later, the cells were harvested and the levels of soluble and insoluble IRAR assessed. In the cytosolic fractions, the level of IRAR increases in direct proportion to the MOI employed. In the range examined in the experiment shown in Fig. 2A (MOI 50-800), the vast majority of AR accumulates as a soluble protein, and only a minor proportion is detected in the pellet (insoluble) fraction. Although an increased amount of AR is detected in the soluble fraction, at higher MOI values an increased proportion accumulates in a denatured, insoluble state (Fig. 2B).

\section{AR expressed following infection with the recombinant adenovirus is functional in ligand-binding and transcriptional assays}

The ability to produce large amounts of intact hAR would be of greatest value if the expressed receptor retained the properties of the native protein, 
A.

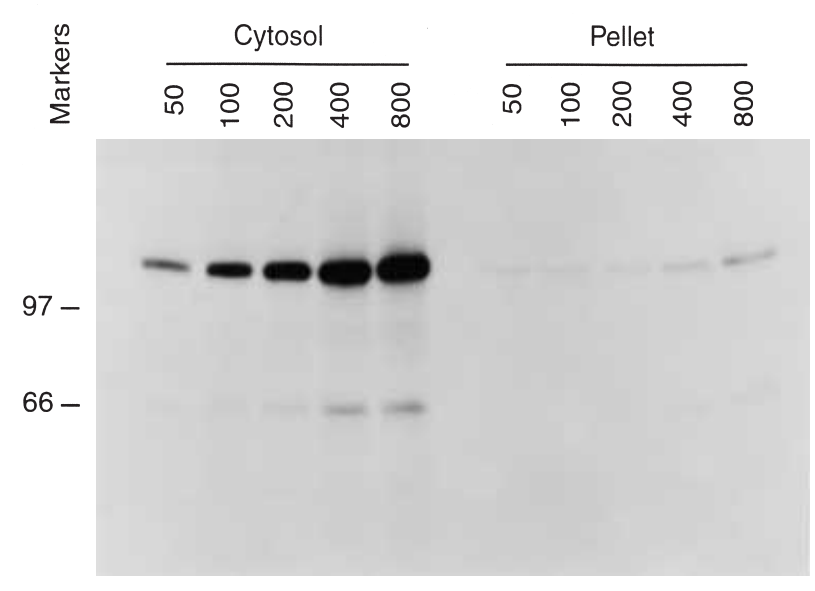

B.
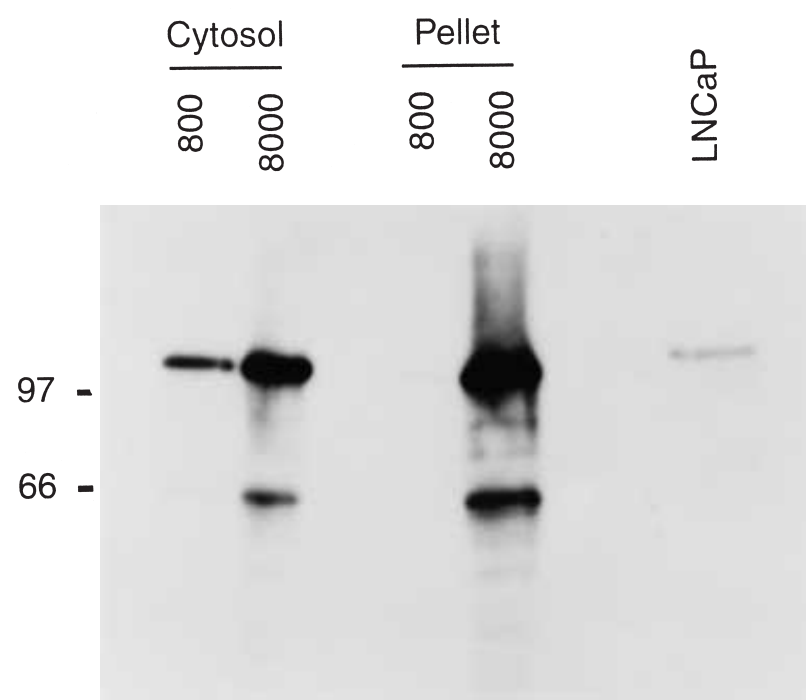

FIGURE 2. MOI determines the level and nature of AR that is synthesized. At $80 \%$ confluence, $10 \mathrm{~cm}$ plates of CV1 cells were infected with the Ad His AR using varying MOIs (50, 100, 200, 400, 800 and 8000). At 48 h, the cells were harvested and fractionated into cytosol and pellet. The individual fractions were analyzed on a $7 \cdot 5 \%$ SDS polyacrylamide gel and transferred to nitrocellulose. IRAR was detected using an antibody directed at the amino terminus of hAR (U402). Equivalent portions of cytosol and pellet were analyzed. At lower MOIs, predominantly soluble AR accumulates (A), while at higher MOIs (B) increased amounts are detected in the pellet fraction. The migration of the immunoreactive AR in the AR-expressing human prostate cancer cell line, $\mathrm{LNCaP}$, is shown at the right. The positions of molecular mass markers are indicated.

including the capacity to bind ligand and regulate transcription. The ligand binding detected in cells infected with this recombinant adenovirus recapitulated properties of the native receptor, as assessed by ligand-binding affinity (Fig. 3A) and specificity (Fig. 3B). As shown in Table 1, high levels of ligand binding could be detected in the infected cells at levels that closely paralleled the quantities of IRAR detected at 24 and $48 \mathrm{~h}$. Of interest, the levels of specific androgen binding consistently fell at $72 \mathrm{~h}$, compared with the levels measured at 24 and $48 \mathrm{~h}$ (Fig. 3C). This decline occurred despite the progressive increase of IRAR that occurred throughout the $72 \mathrm{~h}$ period (Table 1 and Fig. 1).

The ability to express hAR uniformly in populations of cells by infection with Ad His hAR permits a variety of experiments examining AR function to be conducted. Specifically, this technique permits a direct assessment of AR function under conditions in which the character and level of AR expressed in the target cells can be carefully controlled. In the experiment shown in Table 2, CV1 cells were infected with adenoviruses containing the MMTV luciferase reporter alone or in combination with the adenovirus encoding hAR. Assays of cells treated with no hormone or with $\mathrm{Mb}$ following infection with the MMTV-luciferase adenovirus alone showed no change in the level of luciferase reporter gene activity. Cells infected with both the reporter and hAR expression adenoviruses, however, showed dramatic increases of luciferase activity following hormone stimulation. Although the levels of reporter gene activity generally paralleled the levels of AR in these experiments, at MOI levels between 400 and 800 , reporter gene activity plateaued and then decreased. These changes occurred despite the accumulation of increased levels of receptor as detected by monolayer binding and immunoblot assays (Fig. 4).

\section{DISCUSSION}

In experiments designed to express $\mathrm{AR}$ in nonmammalian cells, we encountered two properties of hAR that limited the amount of the receptor protein produced in native form. The first was traced to characteristics inherent to the hormone-binding domain of hAR, as expression of hAR - either the intact protein or a fusion protein containing the hormone-binding domain - led to the accumulation of a large proportion of AR molecules that were either incapable of binding hormone or insoluble (Cooper et al. 1996). These findings are most consistent with the depletion of levels of factor(s) needed to fold the AR into a state in which it was soluble and competent to bind ligand. The second encountered in the course of attempts to express the 

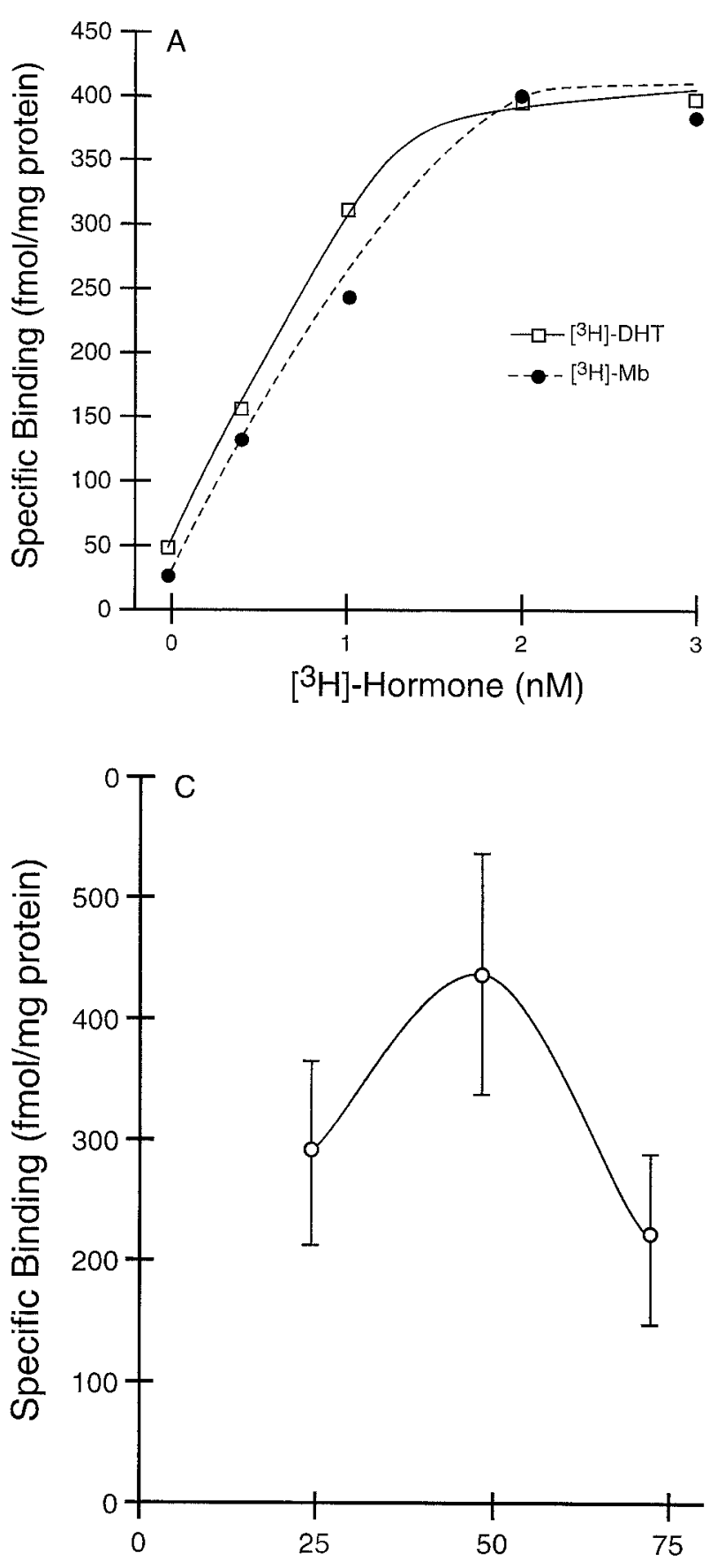

Time Following Infection (hours)

full-length receptor in bacteria and in yeast revolved around the finding that sequences within the amino terminus of the receptor are highly susceptible to proteolysis. Thus, when AR - or fusion proteins containing AR amino-terminal segments are expressed in these cell types, only a small

www.endocrinology.org

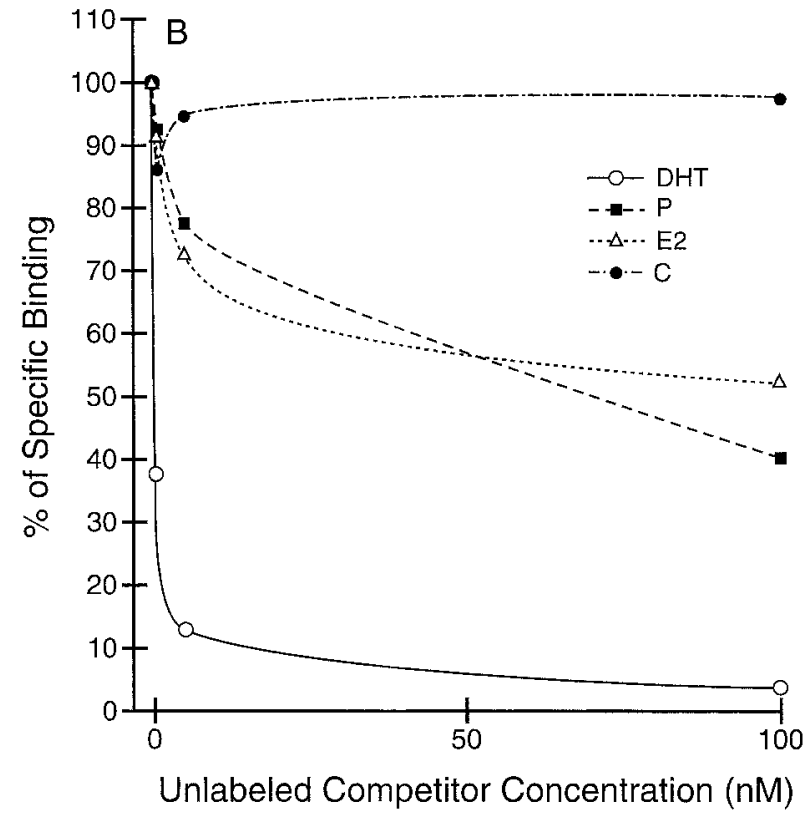

FIGURE 3. Ligand-binding analyses of hAR expression in CV1 monolayers following infection with the Ad His AR. (A) CV1 cells were plated in four-well plates at a density of $4 \times 10^{5}$ cells per well. Sixteen hours later, cells were infected with Ad His AR at $800 \mathrm{MOI}$. At $48 \mathrm{~h}$ following infection, the specific binding was determined. Monolayer cells were incubated for $1 \mathrm{~h}$ at $37^{\circ} \mathrm{C}$ with increasing concentration of $\left[{ }^{3} \mathrm{H}\right] \mathrm{DHT}$ or $\left[{ }^{3} \mathrm{H}\right] \mathrm{Mb}(0 \cdot 1-3 \mathrm{nM})$ with or without a 200 -fold excess of unlabeled DHT or Mb respectively. Half-maximal binding was observed at a concentration of $0.6 \mathrm{nM}$ for both DHT and Mb. (B) CV1 cells were plated in four-well plates at a density of $4 \times 10^{5}$ cells. Sixteen hours later, cells were infected with Ad His AR at a MOI of 800 . At $48 \mathrm{~h}$ after infection, specific androgen binding was determined. Monolayers cells were incubated for $1 \mathrm{~h}$ at $37{ }^{\circ} \mathrm{C}$ with $2 \mathrm{nM}\left[{ }^{3} \mathrm{H}\right] \mathrm{DHT}$ in the presence of various concentrations of unlabeled competitor steroids: DHT, cortisol (C), 17 $\beta$-estradiol (E2) and progesterone (P). (C) CV1 cells were plated in four-well plates at a density of $4 \times 10^{5}$ cells. Sixteen hours later, cells were infected with Ad His AR at an MOI of 800. Monolayer-binding assays were performed at varying times following infection. The figure depicts the results of three separate experiments. The conditions used in these experiments parallel those used in immunoblot experiments such as that depicted in Fig. 1. Note that the level of binding declines, even though the level of IRAR expression increases.

proportion of the resulting protein molecules accumulate as intact receptors (Cooper et al. 1996).

The experiments reported here were designed to address these difficulties. In contrast to our experiences in non-mammalian cells, our experiments indicated that the full-length AR was 
TABLE 1. AR expression measured using ligand-binding and immunoblot assays following infection of CV1 cells with the $\mathrm{pAC}-\mathrm{AR}$ recombinant adenovirus. Parallel cultures of cells infected with the recombinant adenovirus encoding the hAR at a single MOI (800). At different time points after infection, the levels of AR expression were measured using whole-cell ligand-binding assays and immunoblot analyses. The means \pm the standard deviations derived from three separate binding experiments are presented. Densitometry performed on one representative immunoblot was used to quantitate soluble IRAR and values are expressed in arbitrary density units (DU)

\begin{tabular}{llc} 
& $\begin{array}{l}\text { Specific binding } \\
\text { (fmol/mg protein) }\end{array}$ & \multicolumn{1}{l}{$\begin{array}{l}\text { Soluble IRAR } \\
\text { (DU/mg protein })\end{array}$} \\
\cline { 2 - 2 } $\begin{array}{l}\text { Time following } \\
\text { infection }(\mathrm{h})\end{array}$ & & \\
24 & $288 \pm 76$ & 550 \\
48 & $434 \pm 99$ & 804 \\
72 & $217 \pm 70$ & 1531 \\
\hline
\end{tabular}

stable when expressed at high level in a variety of different mammalian cell types (data not shown). Furthermore, our experiments suggested that AR expression could be increased considerably above physiologic levels without an increase in the accumulation of insoluble or non-binding forms of the receptor protein (M J McPhaul, unpublished observations).

For this reason, we constructed Ad His hAR, a recombinant adenovirus vector capable of directing the expression of hAR in a variety of mammalian cell types. Characterization of the AR protein that

TABLE 2. Function of the AR expressed in CV1 cells following infection with the Ad His hAR adenovirus. Cells were infected with varying MOIs of the recombinant adenovirus encoding the hAR and a constant quantity (MOI 250) of a second adenovirus carrying the MMTV luciferase reporter cassette (Shih et al. 1991). Twenty-four hours following infection, the medium was removed and replaced with medium containing $5 \%$ charcoal-stripped serum containing either no hormone or mibolerone. The incubations were continued for an additional $48 \mathrm{~h}$. At the time, the cells were lysed and assayed to determine the levels of luciferase activity. The means \pm the standard deviations of three independent measurements are presented

Luciferase activity

\begin{tabular}{|c|c|}
\hline No hormone & Mibolerone (2 nM) \\
\hline $3279 \pm 245$ & $4507 \pm 689$ \\
\hline $3572 \pm 481$ & $60152 \pm 5406$ \\
\hline $8887 \pm 1863$ & $228117 \pm 43724$ \\
\hline $7836 \pm 1515$ & $376427 \pm 31324$ \\
\hline
\end{tabular}

\section{Ad His hAR} (MOI)

0

100

200

400

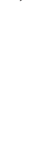

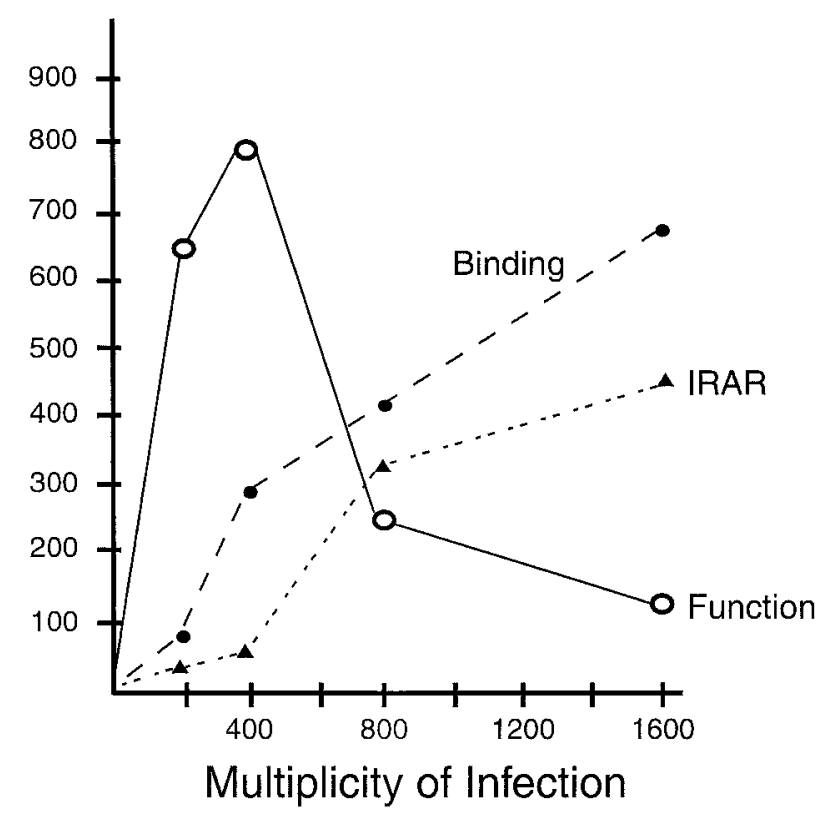

FIGURE 4. Comparison of the level of function, binding and IRAR expression of AR expressed in CV1 cells following infection with the Ad His AR. CV1 cells were co-infected with varying MOIs of the recombinant adenovirus encoding hAR and a constant MOI of a second adenovirus carrying the MMTV luciferase reporter cassette (Shih et al. 1991). Twenty-four hours following infection, the medium was removed and replaced with medium containing 5\% charcoal-stripped serum containing either no hormone or $2 \mathrm{nM} \mathrm{Mb}$. Cells were lysed and then assayed to determine the levels of luciferase activity after $48 \mathrm{~h}$. Analyses of the levels of soluble IRAR and ligand binding were performed in parallel. Under optimal conditions (MOI 800), levels of 2-4 times that detected in the LNCaP cell line can be measured in ligand-binding assays. At lower MOIs, the levels of IRAR, binding and function parallel one another. At higher MOIs, function declines despite increased levels of IRAR and binding, suggesting the exhaustion of factors present in limiting concentrations. The ordinate values employ the same scale, but represent luciferase activity for function (light units measured $\times 10^{-2}$ ), specific binding (fmol/mg protein) and arbitrary density units (for IRAR). The experiment depicted is representative of three separate experiments.

is expressed following infection of recipient cells with the virus yielded results consistent with expectations based on previous cell transfection assays. At low levels of expression (low MOI), abundant, soluble, immunoreactive, intact $\mathrm{AR}$ is detected. This protein displays the capacity to bind ligand with high affinity and demonstrates the expected specificity in ligand-binding and competition experiments. The expressed receptor retains 
substantial activity in assays of reporter gene function.

As described above, prior experiments have noted that two distinct transitions appear to characterize the AR that is synthesized when expressed at high levels in bacteria (Cooper et al. 1996). As the level of AR expression is progressively increased, the level of ligand binding does not increase in parallel with the level of IRAR that can be measured, suggesting that the proportion of AR molecules incapable of binding ligand increases as the level of AR expression rises. This shift occurs even though the receptor remains in the soluble, non-aggregated fraction. The second transition occurs as the level of AR expression is increased many-fold above physiologic levels and is marked by the progressive accumulation of AR in the insoluble, aggregated state. We have interpreted both transitions as suggesting the depletion of factors or the saturation of pathways critical for the folding of the AR to a state that is soluble and capable of binding ligand in bacteria.

The present work demonstrates that subtle differences can be observed when such experiments are conducted in mammalian cells. As in bacteria, at low levels of expression the synthesis of soluble forms of AR predominates. At high levels of expression in both bacteria and mammalian cells, the proportion of insoluble receptor forms increases. In contrast to experiments performed in bacteria, however, the levels of expression of AR forms that are capable of binding hormone appear to closely parallel the levels of soluble IRAR that accumulates over a broad range of expression (Fig. 4). These differences suggest that the expression of AR in mammalian cells may result in the production of preparations composed of a high proportion of molecules competent to bind ligand.

Using recombinant adenoviruses to express hAR permits a number of different types of experiments to examine the basis of these changes in solubility and ligand binding by AR. Isolation and characterization of native AR complexes from cells infected with varying levels of the Ad His hAR should permit the identification of protein chaperones associated with $\mathrm{AR}$ when expressed at different levels. Changes in the composition of such AR complexes as they lose the capacity to bind ligand or as the proportion of insoluble receptor increases may help to identify partners critical to the correct folding of the receptor protein to its native state.

In addition to studies on the folding and processing of AR, cells infected with Ad His hAR represent sources of AR protein at levels that exceed those which can be obtained from most native

www.endocrinology.org sources. As such, infection of cells with Ad His hAR will permit the production of large quantities of recombinant $\mathrm{AR}$ that display many characteristics of the native receptor protein. Such a resource should allow the characterization of complexes containing $\mathrm{AR}$, in both the presence and absence of ligand. The engineering of similar adenoviruses encoding receptors containing selected mutations within the AR reading frame will facilitate a direct examination of the effects that such mutations have on the assembly of multiprotein complexes containing AR.

Finally, the infection of cells with Ad His hAR directs the uniform expression of $\mathrm{AR}$ in cultured cells. As such, this recombinant adenovirus can be adapted to examine the function of AR in virtually any mammalian cell type. While this has utility in studies of AR function per se, it also has implications for use in the testing of AR function in fibroblast strains established from patients with apparent defects of receptor function (McPhaul et al. 1993, 1997, Alléra et al. 1995). This application should allow the ability to discriminate between cells that display defects of AR function due to defects of AR itself and those that are defective in factors necessary for normal AR activity.

\section{ACKNOWLEDGEMENTS}

We gratefully acknowledge the expert assistance of Jo Ann Abbott in the preparation of this manuscript. Grant support was from: Robert A Welch Foundation \#I-1090; National Institutes of Health \#DK03892, DK47657.

\section{REFERENCES}

Alléra A, Herbst MA, Griffin JE, Wilson JD, Schweikert H-U \& McPhaul MJ 1995 Mutations of the androgen receptor coding sequence are infrequent in patients with isolated hypospadias. Fournal of Clinical Endocrinology and Metabolism 80 2697-2699.

Becker TC, Noel RJ, Coats WS, Gomez-Foix AM, Alam T, Gerard RD \& Newgard CB 1994 Use of recombinant adenovirus for metabolic engineering of mammalian cells. Methods in Cell Biology 43 (A) 161-189.

Beitel LK, Sabbaghian N, Alarifi A, Alvarado C, Pinsky L \& Trifiro M 1985 Characterization of normal and pointmutated human androgen receptors expressed in the baculovirus system. Fournal of Molecular Endocrinology 15 117-128.

Caplan AJ, Langley E, Wilson EM \& Vidal J 1995 Hormonedependent transactivation by the human androgen receptor is regulated by a dnaJ protein. Fournal of Biological Chemistry $2705251-5257$.

Chang C, Whelan CT, Popovich TC, Kokontis J \& Liao S 1989 Fusion proteins containing androgen receptor sequences and their use in the production of poly- and monoclonal 
anti-androgen receptor antibodies. Endocrinology 125 1097-1099.

Chang C, Wang C, DeLuca HF, Ross TK \& Shih CC 1992 Characterization of human androgen receptor overexpressed in the baculovirus system. PNAS 89 5946-5950.

Cooper B, Gruber JA \& McPhaul MJ 1996 Hormone-binding and solubility properties of fusion proteins containing the ligand-binding domain of the human androgen receptor. Fournal of Steroid Biochemistry and Molecular Biology 57 251-257.

Freeman BC, Felts SJ, Toft DO \& Yamamoto KR 2000 The p23 molecular chaperones act at a late step in intracellular receptor action to differentially affect ligand efficacies. Genes and Development 14 422-434.

Husmann DA, Wilson CM, McPhaul MJ, Tilley WD \& Wilson JD 1990 Antipeptide antibodies to two distinct regions of the androgen receptor localize the receptor protein to the nuclei of target cells in the rat and human prostate. Endocrinology 126 2359-2368.

Kallio PJ, Palvimo JJ, Mehto M, Xie YB, Sui YP \& Janne OA 1993 Analysis of baculovirus-expressed androgen receptors. Annals of the New York Academy of Sciences 684 233-234.

Liu J \& DeFranco DB 1999 Chromatin recycling of glucocorticoid receptors: implications for multiple roles of heat shock protein 90. Molecular Endocrinology 13 355-365.

McPhaul MJ, Deslypere J-P, Allman DR \& Gerard RD 1993 The adenovirus-mediated delivery of a reporter gene permits the assessment of androgen receptor function in genital skin fibroblast cultures. Fournal of Biological Chemistry 268 26063-26066.

McPhaul MJ, Schweikert H-U \& Allman DR 1997 Assessment of androgen receptor function in genital skin fibroblasts using a recombinant adenovirus to deliver an androgenresponsive reporter gene. Fournal of Clinical Endocrinology and Metabolism 82 1944-1948.

Mak P, Young CY \& Tindall DJ 1994 A novel yeast expression system to study androgen action. Recent Progress in Hormone Research 9 347-352.

Mangelsdorf DJ, Thummel C, Beato M, Herrlich P, Schutz G, Umesono K, Blumberg B, Kastner P, Mark M \& Chambon P 1995 The nuclear receptor superfamily: the second decade. Cell 83 835-839.

Nemoto T, Ohara-Nemoto Y \& Ota M 1992 Association of the 90-kDa heat shock protein does not affect the ligand-binding ability of androgen receptor. Fournal of Steroid Biochemistry and Molecular Biology 42 803-812.
Pratt WB \& Toft DO 1997 Steroid receptor interactions with heat shock protein and immunophilin chaperones. Endocrine Reviews 18 306-360.

Purvis IJ, Chotai D, Dykes CW, Lubahn DB, French FS, Wilson EM \& Hobden AN 1991 An androgen-inducible expression system for Saccharomyces cerevisiae. Gene 106 $35-42$.

Rana S, Bisht D \& Chakraborti PK 1998 Activation of rat androgen receptor by androgenic ligands is unaffected by antiandrogens in Saccharomyces cerevisiae. Gene 209 $247-254$

Roehrborn CG, Zoppi S, Gruber JA, Wilson CM \& McPhaul MJ 1992 Expression and characterization of full-length and partial human androgen receptor fusion proteins. Implications for the production and applications of soluble steroid receptors in Escherichia coli. Molecular and Cellular Endocrinology 84 1-14.

Shih W, Mears T, Bradley DJ, Parandoosh Z \& Weinberger C 1991 An adenoviral vector system for functional identification of nuclear receptor ligands. Molecular Endocrinology 5 300-309.

Smith DF, Whitesell L \& Katsanis E 1998 Molecular chaperones: biology and prospects for pharmacological intervention. Pharmacological Reviews 50 493-514.

Snoek R, Rennie PS, Kasper S, Matusik RJ \& Bruchovsky N 1996 Induction of cell-free, in vitro transcription by recombinant androgen receptor peptides. Fournal of Steroid Biochemistry and Molecular Biology 59 243-250.

Tilley WD, Marcelli M, Wilson JD \& McPhaul MJ 1989 Characterization and expression of a cDNA encoding the human androgen receptor. PNAS 86 327-331.

Wong CI, Zhou ZX, Sar M \& Wilson EM 1993 Steroid requirement for androgen receptor dimerization and DNA binding. Modulation by intramolecular interactions between the $\mathrm{NH}_{2}$-terminal and steroid-binding domains. Fournal of Biological Chemistry 268 19004-19012.

Young CY-F, Qiu S, Prescott JL \& Tindall DJ 1990 Overexpression of a partial human androgen receptor in E. coli: characterization of steroid binding, DNA binding, and immunological properties. Molecular Endocrinology $\mathbf{4}$ 1841-1849.

RECEIVED IN FINAL FORM 6 June 2001 ACCEPTED 20 July 2001 